\title{
Role of Metallothionein and Cysteine-Rich Intestinal Protein in the Regulation of Zinc Absorption by Diabetic Rats
}

\author{
OSCAR ESCOBAR, MANUEL SANDOVAL, ALFONSO VARGAS, AND JAMES M. HEMPE
}

Department of Pediatrics, Divisions of Endocrinology [O.E., A.V.] and Gastroenterology and Nutrition [M.S., J.M.H.], Louisiana State University School of Medicine, New Orleans, Louisiana 70112

\section{ABSTRACT}

\begin{abstract}
Hyperzincuria and low $\mathrm{Zn}$ absorption in diabetic animals and humans have prompted speculation that diabetics are more susceptible to $\mathrm{Zn}$ deficiency. There is little information, however, describing the effects of diabetes on the biochemical mechanisms of intestinal $\mathrm{Zn}$ transport. We evaluated $\mathrm{Zn}$ absorption in streptozotocin-induced diabetic rats based on a model of $\mathrm{Zn}$ transport in which cysteine-rich intestinal protein serves as an intracellular carrier that is inhibited by metallothionein (MT). Apparent absorption and retention of $\mathrm{Zn}$ and $\mathrm{Cu}$ in rats fed a purified diet were measured in a balance study $15-17 \mathrm{~d}$ after induction of diabetes. The rate of ${ }^{65} \mathrm{Zn}$ absorption from isolated intestinal segments, molecular distribution of ${ }^{65} \mathrm{Zn}$ in mucosal cytosol, and tissue MT levels were measured on d 20-22. Food consumption, and thus $\mathrm{Zn}$ and $\mathrm{Cu}$ intake, by diabetic rats was twice that of controls. Although fractional absorption (percent) of $\mathrm{Zn}$ and $\mathrm{Cu}$ was lower in the diabetic rats, net absorption $(\mu \mathrm{g} / 100 \mathrm{~g}$ body weight/d) was higher. The higher net absorption in the diabetic group was offset, however, by higher urinary excretion, so that $\mathrm{Zn}$ and $\mathrm{Cu}$ retention was similar in both groups of animals. Low fractional absorption is attributable to the down-regulation of intestinal $\mathrm{Zn}$ transport, as indicated by the lower rate of ${ }^{65} \mathrm{Zn}$
\end{abstract}

Diabetes is uniformly characterized by hyperzincuria in studies with humans (1-5) or animal models with either spontaneous or chemically induced diabetes $(6-8)$. Controversy persists, however, regarding the effects of diabetes on $\mathrm{Zn}$ absorption and other aspects of $\mathrm{Zn}$ metabolism and homeostasis. Using a variety of methods, experimental models, and measures of $\mathrm{Zn}$ absorption, different investigators have interpreted their results to indicate decreased (9-11), increased $(4$, $12)$, or no difference $(13,14)$ in $\mathrm{Zn}$ absorption by diabetics. Similar inconsistencies regarding an effect on serum $\mathrm{Zn}$ concentration are also evident $(1-8,10-16)$. Conclusive evidence of high urinary $\mathrm{Zn}$ loss combined with limited evidence of depressed $\mathrm{Zn}$ absorption has prompted speculation that diabetics may be at greater risk of $\mathrm{Zn}$ deficiency $(3,10,15,17)$, and

Received June 30, 1994; accepted October 1, 1994.

Correspondence: J. M. Hempe, Ph.D., Department of Pediatrics, Louisiana State University School of Medicine, 1542 Tulane Ave., New Orleans, LA 70112. absorption from isolated intestinal segments in the diabetic rats. Down-regulation of intestinal transport is in turn attributable to higher concentrations of intestinal MT, which resulted in more ${ }^{65} \mathrm{Zn}$ in the mucosal cytosol bound to $\mathrm{MT}$, an inhibitor of $\mathrm{Zn}$ transport, and less to cysteine-rich intestinal protein. These observations are similar to those previously described in rats consuming normal amounts of a diet containing excess $\mathrm{Zn}$ and are consistent with an antagonistic relationship between cysteinerich intestinal protein and $\mathrm{MT}$ in $\mathrm{Zn}$ transport. The results suggest that decreased $\mathrm{Zn}$ absorption in diabetic rats is not a disease-related defect in $\mathrm{Zn}$ transport but instead is a homeostatic response to high $\mathrm{Zn}$ intake caused by overconsumption of a diet with a moderate Zn content. (Pediatr Res 37: 321-327, 1995)

BW, body weight

\section{Abbreviations}

CRIP, cysteine-rich intestinal protein

HEPES, $N$-2-hydroxyethylpiperazine- $N$ '-2-ethanesulfonic acid MT, metallothionein

IDDM, insulin-dependent diabetes mellitus STZ, streptozotocin

that dietary $\mathrm{Zn}$ supplementation should be recommended (15, 17). However, because excessive $\mathrm{Zn}$ intake may inhibit normal $\mathrm{Cu}$ metabolism $(18,19)$, more conclusive evidence of decreased $\mathrm{Zn}$ absorption and risk of $\mathrm{Zn}$ deficiency is needed before dietary $\mathrm{Zn}$ supplements can be confidently recommended to diabetic patients.

Until recently, this evidence has been unavailable because of limited information about the biochemical mechanisms of intestinal $\mathrm{Zn}$ transport. It has been recognized for some time that $\mathrm{Zn}$ absorption is inversely correlated with intestinal concentrations of MT, a low-molecular weight intracellular Zn-binding protein $(20,21)$. Because intestinal MT gene expression is positively correlated with dietary $\mathrm{Zn}$ intake, it was suggested that MT has an essential role as a "mucosal block" in the homeostatic regulation of $\mathrm{Zn}$ transport during periods of high $\mathrm{Zn}$ intake. Although several studies have reported elevated levels of MT in livers and kidneys of diabetic rats $(12,16,22)$, 
an effect of diabetes on intestinal MT has not been demonstrated. High liver and kidney MT concentration in diabetics is not considered indicative of high $\mathrm{Zn}$ status, because stress, glucocorticoid hormones, IL, and other factors also may mediate MT synthesis in these tissues $(21,23-26)$. The intestine, in contrast, is refractory to most mediators of liver MT synthesis other than heavy metals $(23,25-28)$.

Further insight into a possible mechanism of intestinal $\mathrm{Zn}$ transport followed the identification of CRIP in the soluble fraction of rat intestinal mucosa $(29,30)$. It was shown that in rats fed a moderate amount of $\mathrm{Zn}$, CRIP binds a large proportion of ${ }^{65} \mathrm{Zn}$ entering the cell from the lumen, whereas very little was bound to MT. In contrast, ${ }^{65} \mathrm{Zn}$ bound to CRIP, and MT was markedly reduced and increased, respectively, in rats fed a high-Zn diet $(180 \mathrm{mg} / \mathrm{kg})$ that induces intestinal MT. It was concluded that high $\mathrm{Zn}$ intake stimulated the synthesis of intestinal MT, which inhibited binding and transport of $\mathrm{Zn}$ by CRIP. A model of $\mathrm{Zn}$ absorption was proposed in which CRIP serves as a diffusible intracellular carrier in transcellular mu$\operatorname{cosal} \mathrm{Zn}$ transport, whose function is competitively inhibited by MT to limit absorption and maintain $\mathrm{Zn}$ homeostasis during periods of high $\mathrm{Zn}$ intake.

The CRIP gene is developmentally regulated and predominantly expressed in the intestine $(31,32)$. It is also stimulated by glucocorticoid hormones in neonatal intestine $(32,33)$, suggesting a possible role in intestinal development. Unlike MT, CRIP gene expression is not regulated by short-term changes in dietary $\mathrm{Zn}$ (34), suggesting that homeostatic regulation of $\mathrm{Zn}$ absorption by acute high $\mathrm{Zn}$ intake is mediated primarily through the up-regulation of intestinal MT gene expression. Because the low $\mathrm{Zn}$ absorption reported in diabetics may be related to changes in intestinal CRIP or MT synthesis and their interaction, the present study examined $\mathrm{Zn}$ and $\mathrm{Cu}$ absorption and metabolism in a rat model of IDDM in the context of the model of intestinal $\mathrm{Zn}$ transport described above.

\section{METHODS}

Animals and diet. Male Sprague-Dawley rats (125-150 g) were obtained from Harlan Sprague-Dawley (Indianapolis, IN) and individually housed in stainless-steel cages in an environmentally controlled room $\left(25^{\circ} \mathrm{C}, 12-\mathrm{h} / 12-\mathrm{h}\right.$ light/dark cycle). Food and deionized, distilled water were supplied ad libitum 5 $\mathrm{d}$ before the experiment and throughout the study. The composition of the egg white-based diet (Research Diets, Inc., New Brunswick, NJ) was based on the AIN-76 formulation $(35,36)$ and supplemented with $\mathrm{ZnCO}_{3}$ and $\mathrm{CuSO}_{4}$. The diet was analyzed by atomic absorption spectrophotometry to contain $31 \mathrm{mg}$ of $\mathrm{Zn}$ and $6 \mathrm{mg}$ of $\mathrm{Cu} / \mathrm{kg}$ of diet. Pair feeding to remove the confounding effects of food intake was not used in this study, because diabetic rats pair fed to the intake level of control rats exhibited high mortality in pilot studies. Care and treatment of experimental animals received prior institutional approval and followed recommended guidelines (37).

Materials. Unless otherwise stated, all chemicals were at least reagent grade and were obtained from Sigma Chemical Co. (St. Louis, MO) or U.S. Biochemical (Cleveland, OH).
Diabetes induction. After dietary acclimation, eight rats were randomly selected and injected s.c. with STZ to induce diabetes. Each dose (65 mg of STZ/kg BW) was prepared by dissolving $0.02 \mathrm{~g}$ of STZ in $0.2 \mathrm{~mL}$ of buffer (sodium citrate, $10 \mathrm{~mol} / \mathrm{L}, \mathrm{pH} 4.5$ ) immediately before injection. Controls received a sham injection of buffer without STZ. Blood glucose levels were regularly monitored (One Touch II, Lifescan, Inc., Milpitas, CA) using one drop of whole blood obtained by clipping the tip of the tail between two glass microscope slides. Severe hyperglycemia, i.e. blood glucose greater than 11.1 $\mathrm{mmol} / \mathrm{L}(200 \mathrm{mg} / \mathrm{dL})$, was confirmed in all but one of the STZ-injected rats $48 \mathrm{~h}$ after injection. The nonresponding rat was removed from the study.

$\mathrm{Zn}$ and $\mathrm{Cu}$ balance study. All animals were individually housed in suspended stainless-steel metabolic cages from 14 to $21 \mathrm{~d}$ after the induction of diabetes. Food and water intake were recorded and urine and feces quantitatively collected daily on $\mathrm{d} \mathrm{15-17,} \mathrm{inclusive.} \mathrm{The} \mathrm{Zn}$ contents of the diet, urine, and feces were determined by atomic absorption spectrophotometry as described below. Apparent absorption and retention of $\mathrm{Zn}$ and $\mathrm{Cu}$ were calculated as follows.

Apparent absorption data are presented as either fractional or net absorption. Fractional absorption is the amount of $\mathrm{Zn}$ or $\mathrm{Cu}$ absorbed expressed as a proportion of intake; these data have been converted to percentages for ease of interpretation. Net absorption represents the amount of $\mathrm{Zn}$ or $\mathrm{Cu}$ absorbed and is expressed as both $\mu \mathrm{g}$ per $\mathrm{d}$ and $\mu \mathrm{g}$ per $\mathrm{d} / 100 \mathrm{~g}$ BW to normalize for differences in BW.

$\mathrm{Zn}$ and $\mathrm{Cu}$ measurements. The $\mathrm{Zn}$ and $\mathrm{Cu}$ contents of diet, urine, feces, plasma, and HPLC fractions were measured by air-acetylene flame atomic absorption spectrophotometry (model 3030B, Perkin Elmer, Norwalk, CT). Plasma, collected by cardiac puncture in heparinized syringes immediately after measurement of the rate of $\mathrm{Zn}$ absorption, was diluted 1:4 (vol/vol) in deionized, distilled water. Diet and homogenized feces were dried in a convection oven to constant weight, then ashed by microwave digestion (model MDS 2000, CEM, Matthews, NC). A measured amount ( $\sim 0.2 \mathrm{~g}$ ) of dried diet or feces was transferred to a Teflon digestion vessel, mixed with $5 \mathrm{~mL}$ of $\mathrm{HNO}_{3}$ and $2 \mathrm{~mL}$ of $\mathrm{HCl}$, then digested for 5 and $30 \mathrm{~min}$ at 50 and $100 \%$ power, respectively. After cooling, each sample was diluted to $100 \mathrm{~mL}$ with deionized, distilled water and analyzed.

Rate of $\mathrm{Zn}$ absorption. The rate of $\mathrm{Zn}$ absorption from isolated intestinal segments was measured on d 20-22 after the induction of diabetes. Each rat was anesthetized $(60 \mathrm{mg}$ of sodium pentobarbital/kg BW) and placed on a warm heating pad to maintain surface temperature at approximately $37^{\circ} \mathrm{C}$. After median laparotomy, a $15-\mathrm{cm}$ segment of the proximal small intestine immediately distal to the pancreatic and bile duct was rinsed with $10 \mathrm{~mL}$ of buffered saline (HEPES, 10 $\mathrm{mmol} / \mathrm{L}, \mathrm{pH} 7.5 ; \mathrm{NaCl}, 154 \mathrm{mmol} / \mathrm{L}$ ), ligated, then injected intraluminally with $1 \mathrm{~mL}$ of buffered saline containing 25 $\mu \mathrm{mol} / \mathrm{L} \mathrm{ZnSO}{ }_{4} .7 \mathrm{H}_{2} \mathrm{O}$ and $200 \mathrm{kBq}$ of ${ }^{65} \mathrm{Zn}$ (Du Pont New England Nuclear, Wilmington, DE). The isolated segment was returned to the body cavity for $30 \mathrm{~min}$, then excised and flushed with cold homogenization buffer (HEPES, $10 \mathrm{mmol} / \mathrm{L}$, $\mathrm{pH} 8.0 ; \mathrm{NaCl}, 154 \mathrm{mmol} / \mathrm{L}$; phenylmethylsulfonyl fluoride, 0.2 
$\mathrm{mmol} / \mathrm{L}$; leupeptin, $0.6 \mathrm{mg} / \mathrm{L}$; pepstatin $\mathrm{A}, 0.9 \mathrm{mg} / \mathrm{L}$ ) into a test tube to quantitatively collect the ${ }^{65} \mathrm{Zn}$ remaining in the lumen. The ${ }^{65} \mathrm{Zn}$ content of the luminal fluid and the excised intestinal segment was determined by gamma spectroscopy (model 1272 Clinigamma, Pharmacia LKB, Gaithersburg, MD). Uptake was calculated as disappearance of ${ }^{65} \mathrm{Zn}$ from the lumen, intestinal accumulation of luminal $\mathrm{Zn}$ as the amount of ${ }^{65} \mathrm{Zn}$ remaining in the tissue of the intestinal segment after flushing, and absorption by subtracting intestinal accumulation from uptake. Isotope data were converted to molar concentrations based on the $\mathrm{Zn}$ content of the injected radioisotope solution and converted to rates based on the length of the absorption period.

Molecular distribution of intracellular ${ }^{65} \mathrm{Zn}$. After rinsing, the excised intestinal segment was placed on a cold glass plate and slit longitudinally. The mucosal layer was then removed from the underlying submucosa by gently scraping the luminal surface with a glass microscope slide. Homogenates of intestinal mucosa and liver were prepared 1:3 (wt/vol) in homogenization buffer using a Potter-Elvehjem glass-Teflon tissue grinder. After centrifugation at $40000 \times \mathrm{g}$ for $30 \mathrm{~min}$ at $4^{\circ} \mathrm{C}$ (model RC2-B, Sorval, Newtown, CT), the supernatant fraction was removed and filtered (Millex-GS, $0.22 \mu \mathrm{m}$, Millipore, Bedford, MA). Intracellular Zn-binding constituents were separated by size-exclusion HPLC using a $1 \times 30$-cm Superdex 75 column (Pharmacia, Piscataway, NJ) and were eluted at 0.5 $\mathrm{mL} / \mathrm{min}(\sim 300$ pounds per square inch) with buffered saline (HEPES, $10 \mathrm{mmol} / \mathrm{L}, \mathrm{pH} \mathrm{7.4;} \mathrm{NaCl}, 154 \mathrm{mmol} / \mathrm{L} ; \mathrm{NaN}_{3}, 0.2$ $\mathrm{g} / \mathrm{L})$. The ${ }^{65} \mathrm{Zn}$ and $\mathrm{Zn}$ contents of the collected fractions ( 0.5 $\mathrm{mL}$ ) were determined by gamma spectroscopy and atomic absorption spectrophotometry, respectively. Mean recovery of ${ }^{65} \mathrm{Zn}$ from the Superdex 75 column was $96 \%$ and ranged from 83 to $112 \%$.

MT concentration. The MT concentration of liver and intestinal mucosa was determined by $\left[{ }^{109} \mathrm{Cd}\right] \mathrm{Hb}$ affinity assay as previously described (23).

Statistical analysis. All data are expressed as the mean \pm SEM and were analyzed by unpaired $t$ test. Unless otherwise noted, significant differences between treatments were determined at $p<0.05$. Variance homogeneity was tested by variance ratio, and heterogeneous data were transformed (log or square root) before statistical analysis.

\section{RESULTS}

General metabolism. During the balance study, the diabetic rats exhibited marked hyperphagia, consuming more than twice as much food as controls (Table 1). Polydypsia and polyuria, typically observed in uncontrolled diabetes as a mechanism to increase glucose excretion, were also clearly evident. Despite higher food intake, diabetic rats lost weight during the balance study in marked contrast to the weight gained by the control rats. Mean weight gain for the entire 21-d study was significantly lower in diabetic $(18.5 \mathrm{~g})$ than in control $(116.2 \mathrm{~g})$ rats.

$\mathrm{Zn}$ and $\mathrm{Cu}$ balance. The approximately 2 -fold higher food intake by the diabetic rats resulted in a similar increase in $\mathrm{Zn}$ (Table 2) and $\mathrm{Cu}$ (Table 3) intake. Both urine and fecal $\mathrm{Zn}$ and $\mathrm{Cu}$ excretion were also significantly higher in the diabetic rats than in controls. For a more complete picture of the effect of diabetes on $\mathrm{Zn}$ and $\mathrm{Cu}$ absorption, it is important to evaluate apparent absorption in terms of both fractional and net absorption. Fractional absorption (percent of intake) of $\mathrm{Zn}$ and $\mathrm{Cu}$ was significantly lower in the diabetic rats, indicating downregulation of absorption in response to high $\mathrm{Zn}$ and $\mathrm{Cu}$ intake. However, because intake was higher in the diabetic group, lower fractional absorption resulted in net absorption $(\mu \mathrm{g} / \mathrm{d})$ equal to that observed in control rats. When net absorption was normalized to account for the lower BW of the diabetic rats, net absorption expressed as micrograms per $100 \mathrm{~g} \mathrm{BW/d}$ was significantly higher in the diabetic group. The greater amount of $\mathrm{Zn}$ and $\mathrm{Cu}$ absorbed by the diabetic rats was exactly offset, however, by higher urinary $\mathrm{Zn}$ and $\mathrm{Cu}$ excretion, resulting in $\mathrm{Zn}$ and $\mathrm{Cu}$ retention (absorption minus urinary excretion) that was similar in both groups. These data indicate that, despite markedly higher $\mathrm{Zn}$ and $\mathrm{Cu}$ intakes, the diabetic rats achieved homeostasis by a combination of decreased fractional absorption and increased urinary excretion.

Rate of $\mathrm{Zn}$ absorption. The depressing effect of diabetes on fractional absorption can be explained by the down-regulation of $\mathrm{Zn}$ transport from the lumen determined by measuring ${ }^{65} \mathrm{Zn}$ absorption from in situ isolated intestinal segments (Table 4). Because hyperplasia of the intestinal mucosa is a consistent feature of diabetes $(12,38)$, these data are presented as both net transport (unadjusted) and weight-normalized transport (per gram of intestine) to account for the significant difference in mucosal mass between diabetic and control rats $(1.20$ versus $1.04 \mathrm{~g}$ wet weight $/ 15 \mathrm{~cm}$ intestine, respectively). Net $\mathrm{Zn}$ uptake from the lumen during the $30-\mathrm{min}$ incubation period was similar in both groups. Although not significant $(p=0.09)$, net intestinal accumulation of luminal $\mathrm{Zn}$ was nearly $25 \%$ greater (similar to the increase in mucosal mass) in the diabetic rats than in the controls. In contrast, control rats absorbed nearly twice as much $\mathrm{Zn}$ as the diabetic rats. When normalized values were compared, the rate of $\mathrm{Zn}$ absorption by controls was more than two times greater than that observed in the diabetic rats. These data indicate that lower fractional absorption of the $\mathrm{Zn}$ ingested by the diabetic rats is attributable to a down-regulation of intestinal $\mathrm{Zn}$ transport mechanisms.

Table 1. Effect of diabetes on general metabolism in the rat

\begin{tabular}{|c|c|c|c|c|c|}
\hline Treatment $(n)$ & $\begin{array}{l}\text { Food intake } \\
(\mathrm{g} / \mathrm{d})\end{array}$ & $\begin{array}{l}\text { Water intake } \\
(\mathrm{mL} / \mathrm{d})\end{array}$ & $\begin{array}{l}\text { Urine volume } \\
(\mathrm{mL} / \mathrm{d})\end{array}$ & $\begin{array}{c}\text { Feces wt } \\
(g / d)\end{array}$ & $\begin{array}{l}\text { BW change } \\
(\mathrm{g} / \mathrm{d})\end{array}$ \\
\hline Control (8) & $15.6 \pm 0.4$ & $26.3 \pm 1.0$ & $8.8 \pm 0.7$ & $0.81 \pm 0.07$ & $2.76 \pm 0.63$ \\
\hline Diabetes (7) & $32.9 \pm 1.1$ & $235.5 \pm 10.3$ & $232.2 \pm 12.3$ & $2.29 \pm 0.08$ & $-1.00 \pm 0.45$ \\
\hline$p$ & $<0.0001$ & $<0.0001$ & $<0.0001$ & $<0.0001$ & 0.0004 \\
\hline
\end{tabular}

Values are means \pm SEM. Balance data were collected on d 15-17 after induction of diabetes with STZ. 
Table 2. Zinc balance in rats

\begin{tabular}{|c|c|c|c|c|c|c|c|c|}
\hline \multirow[b]{3}{*}{ Treatment $(n)$} & \multirow[b]{3}{*}{$\begin{array}{c}\mathrm{Zn} \text { intake } \\
(\mu \mathrm{g} / \mathrm{d})\end{array}$} & \multirow{3}{*}{$\begin{array}{c}\text { Urine } \mathrm{Zn} \\
\text { excretion } \\
(\mu \mathrm{g} / \mathrm{d})\end{array}$} & \multirow{3}{*}{$\begin{array}{c}\text { Fecal } \mathrm{Zn} \\
\text { excretion } \\
(\mu \mathrm{g} / \mathrm{d})\end{array}$} & \multicolumn{3}{|c|}{ Apparent $\mathrm{Zn}$ absorption } & & \\
\hline & & & & & & & \multicolumn{2}{|c|}{ Zn retention } \\
\hline & & & & $\begin{array}{c}\text { Fractional } \\
(\%)\end{array}$ & $\mu \mathrm{g} / \mathrm{d}$ & $\begin{array}{c}\mu \mathrm{g} / 100 \mathrm{~g} \\
\mathrm{BW} / \mathrm{d}\end{array}$ & $\mu \mathrm{g} / \mathrm{d}$ & $\begin{array}{c}\mu \mathrm{g} / 100 \mathrm{~g} \\
\mathrm{BW} / \mathrm{d}\end{array}$ \\
\hline Control (8) & $493 \pm 12$ & $6 \pm 1$ & $265 \pm 24$ & $46 \pm 5$ & $229 \pm 25$ & $94 \pm 9$ & $223 \pm 25$ & $92 \pm 9$ \\
\hline Diabetes (7) & $1037 \pm 35$ & $66 \pm 5$ & $797 \pm 34$ & $23 \pm 2$ & $240 \pm 19$ & $144 \pm 5$ & $173 \pm 16$ & $104 \pm 5$ \\
\hline$p$ & $<0.0001$ & $<0.0001$ & $<0.0001$ & 0.0003 & NS & 0.0004 & NS & NS \\
\hline
\end{tabular}

Values are means \pm SEM. Balance data were collected $15-17 \mathrm{~d}$ after induction of diabetes with STZ.

Table 3. Copper balance in rats

\begin{tabular}{|c|c|c|c|c|c|c|c|c|}
\hline \multirow[b]{3}{*}{ Treatment $(n)$} & \multirow{3}{*}{$\begin{array}{c}\mathrm{Cu} \\
\text { intake } \\
(\mu \mathrm{g} / \mathrm{d})\end{array}$} & \multirow{3}{*}{$\begin{array}{l}\text { Urine } \mathrm{Cu} \\
\text { excretion } \\
(\mu \mathrm{g} / \mathrm{d})\end{array}$} & \multirow{3}{*}{$\begin{array}{c}\text { Fecal } \mathrm{Cu} \\
\text { excretion } \\
(\mu \mathrm{g} / \mathrm{d})\end{array}$} & \multicolumn{3}{|c|}{ Apparent $\mathrm{C} \iota$ absorption } & \multirow{2}{*}{\multicolumn{2}{|c|}{$\mathrm{Cu}$ retention }} \\
\hline & & & & \multirow[b]{2}{*}{$\begin{array}{c}\text { Fractional } \\
(\%)\end{array}$} & \multicolumn{2}{|c|}{ Net } & & \\
\hline & & & & & $\mu \mathrm{g} / \mathrm{d}$ & $\begin{array}{c}\mu \mathrm{g} / 100 \mathrm{~g} \\
\mathrm{BW} / \mathrm{d}\end{array}$ & $\mu \mathrm{g} / \mathrm{d}$ & $\begin{array}{c}\mu \mathrm{g} / 100 \mathrm{~g} \\
\mathrm{BW} / \mathrm{d}\end{array}$ \\
\hline Control (8) & $99 \pm 2$ & $8 \pm 1$ & $61 \pm 5$ & $38 \pm 5$ & $38 \pm 5$ & $16 \pm 2$ & $31 \pm 4$ & $13 \pm 2$ \\
\hline Diabetes (7) & $209 \pm 7$ & $24 \pm 2$ & $159 \pm 6$ & $24 \pm 2$ & $50 \pm 5$ & $30 \pm 2$ & $26 \pm 4$ & $16 \pm 2$ \\
\hline$p$ & $<0.0001$ & $<0.0001$ & $<0.0001$ & 0.0205 & NS & 0.0002 & NS & NS \\
\hline
\end{tabular}

Values are means \pm SEM. Balance data were collected $15-17 \mathrm{~d}$ after induction of diabetes with STZ.

Table 4. Zinc absorption from isolated intestinal segments

\begin{tabular}{|c|c|c|c|c|c|c|}
\hline \multirow[b]{2}{*}{ Treatment $(n)$} & \multicolumn{3}{|c|}{ Net transport } & \multicolumn{3}{|c|}{ Weight-normalized transport } \\
\hline & $\begin{array}{l}\text { Uptake } \\
\text { (nmol) }\end{array}$ & $\begin{array}{l}\text { Intestinal accumulation } \\
\text { of Luminal } \mathrm{Zn} \text { (nmol) }\end{array}$ & $\begin{array}{l}\text { Rate of } \mathrm{Zn} \\
\text { absorption } \\
(\mathrm{pmol} / \mathrm{min})\end{array}$ & $\begin{array}{l}\text { Uptake } \\
(\mathrm{nmol} / \mathrm{g})\end{array}$ & $\begin{array}{l}\text { Intestinal accumulation } \\
\text { of luminal } \mathrm{Zn}(\mathrm{nmol} / \mathrm{g})\end{array}$ & $\begin{array}{c}\text { Rate of } \mathrm{Zn} \\
\text { absorption } \\
(\mathrm{pmol} / \mathrm{min} / \mathrm{g})\end{array}$ \\
\hline Control (5) & $16.6 \pm 1.0$ & $10.7 \pm 1.0$ & $196 \pm 12$ & $16.0 \pm 1.1$ & $10.3 \pm 0.8$ & $191.0 \pm 17.5$ \\
\hline Diabetes (4) & $16.3 \pm 0.6$ & $13.2 \pm 0.8$ & $102 \pm 7$ & $13.7 \pm 1.0$ & $11.1 \pm 1.0$ & $86.4 \pm 9.3$ \\
\hline$p$ & NS & NS & 0.0005 & NS & NS & 0.0018 \\
\hline
\end{tabular}

Values are means \pm SEM. Data were collected 20-22 d after induction of diabetes with STZ. Uptake was determined by disappearance of ${ }^{65} \mathrm{Zn}$ from the lumen of a $15-\mathrm{cm}$ isolated segment of proximal small intestine 30 min after injection with $1 \mathrm{~mL}$ of buffered saline containing $25 \mu \mathrm{mol} / \mathrm{L} \mathrm{ZnSO}_{4} \cdot 7 \mathrm{H} \mathrm{H}_{2} \mathrm{O}$ and $200 \mathrm{kBq}$ of ${ }^{65} \mathrm{Zn}$. Intestinal accumulation was based on the amount of ${ }^{65} \mathrm{Zn}$ remaining in the tissue of the intestinal segment. The rate of absorption was calculated by subtracting intestinal accumulation from uptake and dividing by time. Isotope data were converted to molar concentrations based on the $\mathrm{Zn}$ content of the injected radioisotope solution.

Molecular distribution of intracellular $\mathrm{Zn}$ and intestinal $M T$ concentration. The effect of diabetes on the proposed carrier-mediated $\mathrm{Zn}$ transport system involving CRIP and MT was evaluated by measuring MT protein and determining the distribution of total $\mathrm{Zn}$ and ${ }^{65} \mathrm{Zn}$ in mucosal cytosol analyzed by size-exclusion HPLC (Fig. 1). Overall, total $\mathrm{Zn}$ distribution (which includes both luminal $\mathrm{Zn}$ and all other $\mathrm{Zn}$ previously accumulated in the mucosal cells) was similar in both groups of rats, although cytosol from diabetic rats showed a small increase in the amount of $\mathrm{Zn}$ eluting with MT. In contrast, markedly more ${ }^{65} \mathrm{Zn}$ (i.e. $\mathrm{Zn}$ that recently entered the cell from the lumen of the intestine) eluted in fractions containing MT in the diabetic group. Higher ${ }^{65} \mathrm{Zn}$ binding by MT in the diabetic rats was associated with proportionally lower ${ }^{65} \mathrm{Zn}$-binding by both CRIP and higher-molecular weight constituents (see Fig. 1 legend). This evidence of higher intestinal MT in the diabetic rats was supported by data obtained by $\mathrm{Cd}-\mathrm{Hb}$ affinity assay for MT protein (Fig. 2), which showed elevated MT in both liver and intestine of the diabetic rats. Because MT is recognized as an inhibitor of $\mathrm{Zn}$ absorption, these data suggest that the down-regulation of intestinal $\mathrm{Zn}$ transport, and by extension fractional absorption, is attributable to the up-regulation of intestinal MT. Because high intestinal MT resulted in less luminal $\mathrm{Zn}$ bound to CRIP, the inhibitory effect of MT on $\mathrm{Zn}$ transport may be attributable to competitive binding of luminal $\mathrm{Zn}$ between MT and CRIP, the proposed intracellular $\mathrm{Zn}$ carrier.

Blood glucose and plasma $\mathrm{Zn}$ and $\mathrm{Cu}$. Blood glucose analyzed at the time the animals were killed was $25.9 \pm 1.5$ and $4.5 \pm 0.3 \mathrm{mmol} / \mathrm{L}$ in diabetic and control rats, respectively. Plasma $\mathrm{Zn}(2.54 \pm 0.23$ versus $1.77 \pm 0.06 \mu \mathrm{g} / \mathrm{mL})$ and $\mathrm{Cu}$ $(0.89 \pm 0.03$ versus $0.76 \pm 0.04 \mu \mathrm{g} / \mathrm{mL})$ were both significantly higher in the diabetic rats. The amount of $\mathrm{Zn}$ absorbed during the $30-\mathrm{min}{ }^{65} \mathrm{Zn}$ absorption period represented less than $4 \%$ of the $\mathrm{Zn}$ in the plasma and did not contribute significantly to differences in plasma $\mathrm{Zn}$ concentration. These data correlate with the results of the balance data (higher net absorption and higher urinary excretion of $\mathrm{Zn}$ and $\mathrm{Cu}$ ) and suggest that the $\mathrm{Zn}$ and $\mathrm{Cu}$ status of the diabetic rats was elevated compared with controls.

\section{DISCUSSION}

In these experiments, disease-related hyperphagia resulted in $\mathrm{Zn}$ and $\mathrm{Cu}$ consurnption by diabetic rats that was twice that of controls fed the same diet containing a moderate amount of $\mathrm{Zn}$ and $\mathrm{Cu}$ ( 31 and $6 \mathrm{mg} / \mathrm{kg}$ diet, respectively). Because the growth rate of the diabetic rats was markedly lower, it seems likely 


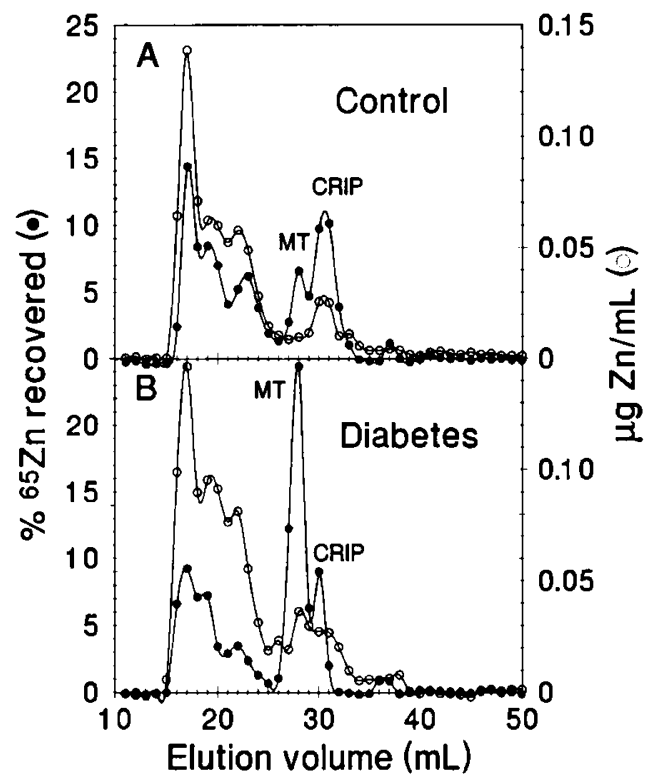

Figure 1. Molecular distribution of ${ }^{65} \mathrm{Zn}$ and total $\mathrm{Zn}$ in cytosol from rat intestinal mucosa determined by size-exclusion HPLC $(1 \times 30-\mathrm{cm}$ Pharmacia Superdex-75; exclusion limit, 100000 molecular weight). In vivo-isolated segments of proximal small intestine were injected intraluminally with ${ }^{65} \mathrm{Zn}$ to measure $\mathrm{Zn}$ absorption and label intracellular $\mathrm{Zn}$-binding constituents. Significantly more ${ }^{6.5} \mathrm{Zn}(p<0.05)$ was bound to MT (32 vs 9\%) and less to CRIP (14 vs 22\%) in cytosol from diabetic rats $(n=4)$ compared with controls $(n=$ 5 ). These data show that $\mathrm{Zn}$ entering the cell from the lumen preferentially binds to MT rather than CRIP and other intracellular constituents when MT levels are elevated.

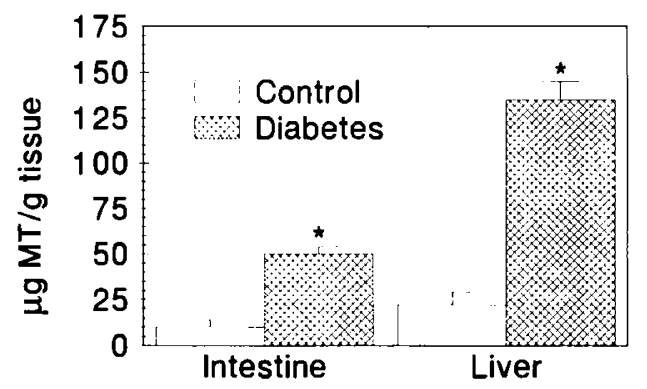

Figure 2. MT protein levels (means $\pm \mathrm{SEM}$ ) measured by $\mathrm{Cd}-\mathrm{Hb}$ affinity assay $21 \mathrm{~d}$ after induction of diabetes with STZ. The MT content of proximal small intestine and liver of the diabetic rats was significantly higher than that of controls. ${ }^{*}, p<0.01$.

that their requirement for these trace elements was also lower. But despite higher intake and lower requirement, the balance data showed that $\mathrm{Zn}$ and $\mathrm{Cu}$ retention by the diabetic rats was similar to that of the controls. These data further indicate that homeostasis was established in diabetic rats by a combination of low fractional absorption and high urinary excretion.

The biochemical basis underlying low fractional absorption by diabetic rats was further evaluated by measuring the rate of ${ }^{65} \mathrm{Zn}$ absorption from in situ isolated proximal intestinal segments. The results showed a lower rate of $\mathrm{Zn}$ absorption in the diabetic rats, indicating that intestinal $\mathrm{Zn}$ transport mechanisms were down-regulated. Measurement of $\mathrm{Zn}$ transport using ${ }^{65} \mathrm{Zn}$ assumes that a similar ${ }^{65} \mathrm{Zn}$-to- $\mathrm{Zn}$ ratio is maintained in both treatment groups. Thus the lower rate of absorption observed in the diabetic rats could be a result of isotope dilution. However, prior studies have shown that intestinal $\mathrm{Zn}$ concentration is not affected by diabetes (16), an observation that is supported in our experiments by the lack of treatment difference in the total $\mathrm{Zn}$ concentration of mucosal cytosol evaluated by HPLC. Similarly, other investigators also have reported that mucosato-lumen $\mathrm{Zn}$ transport is similar (12) or lower (11) in diabetic rats than in controls, and that endogenous $\mathrm{Zn}$ secretion is similar in both groups (12). Furthermore, our protocol minimizes opportunities for isotope dilution by preflushing the intestine, excluding pancreatic and biliary secretions from the isolated intestinal segment, and using a short interval during which absorption is measured. It is therefore unlikely that isotope dilution represents a source of error in the measurement of the rate of $\mathrm{Zn}$ transport in the present experiments.

The observed induction of intestinal MT in the diabetic rats was similar to that previously observed in nondiabetic rats fed a diet containing excess $\mathrm{Zn}(180 \mathrm{mg} / \mathrm{kg}$ diet) for $4 \mathrm{~d}$ (30). Both groups also exhibited altered molecular distribution of intracellular ${ }^{65} \mathrm{Zn}$ in the intestinal mucosa, with proportionally more ${ }^{65} \mathrm{Zn}$ bound to MT and less to CRIP. These data are consistent with the proposed carrier-mediated model of transcellular $\mathrm{Zn}$ transport (30) based on the antagonistic relationship between CRIP and MT. The two studies also indicate that high $\mathrm{Zn}$ intake, attributable either to overconsumption of a diet with a moderate $\mathrm{Zn}$ content or to normal consumption of a diet with a high $\mathrm{Zn}$ content, induces intestinal MT to limit $\mathrm{Zn}$ absorption and maintain homeostasis. Although altered CRIP synthesis also could contribute to the regulation of $\mathrm{Zn}$ homeostasis, it was recently shown that CRIP gene expression was not altered by short-term changes in $\mathrm{Zn}$ status that significantly alter MT synthesis and $\mathrm{Zn}$ absorption (34). Collectively, the results suggest that the down-regulation of $\mathrm{Zn}$ transport observed in the diabetic rats was a homeostatic response to excess $\mathrm{Zn}$ intake that was mediated through an effect of dietary $\mathrm{Zn}$ on MT gene expression and the inhibitory effect of MT on $\mathrm{Zn}$ binding by CRIP.

Evidence of increased intestinal MT in the diabetic rats is both new and seminal to our conclusion that, at least in these experiments, low $\mathrm{Zn}$ absorption was a beneficial homeostatic response to hyperphagia rather than a disease-related defect in $\mathrm{Zn}$ transport. It has long been recognized that tissue MT levels are positively correlated with $\mathrm{Zn}$ status or intake, and that MT has a role in the homeostatic regulation of $\mathrm{Zn}$ and other heavy metals $(20,21)$. Although elevated liver and kidney MT have been reported in diabetic rats previously $(7,12,16,22)$, these observations are not conclusive indicators of high $\mathrm{Zn}$ status, because stress, glucocorticoid hormones, interleukins, and other factors also may mediate MT synthesis in these tissues $(21,23,24,26)$. In contrast, intestinal MT gene expression is refractory to most mediators of liver MT synthesis $(23,26-28)$ but is closely and positively correlated with dietary $\mathrm{Zn}(20,23)$.

Craft and Failla (12) reported no effect of diabetes on percent apparent (fractional) $\mathrm{Zn}$ and $\mathrm{Cu}$ absorption but, similar to our results, showed higher net absorption of $\mathrm{Zn}$ and $\mathrm{Cu}$ per unit of BW. They also reported that the rate of $\mathrm{Zn}$ absorption per gram of intestine from ligated duodenal segments was lower in the diabetic group. Although liver and kidney MT were elevated, the authors observed no difference in the concentration of intestinal MT, measured in this case by $\mathrm{Hg}$ 
affinity assay. Lacking evidence of increased intestinal MT in the diabetic group, the authors concluded that the observed decrease in the rate of absorption was not the result of an intracellular mucosal block attributable to MT, but instead was the result of decreased net influx at the brush border surface. The results of the present study, however, clearly showed by both Cd-Hb affinity assay and by HPLC that intestinal MT is elevated and suggest a mucosal block mediated through a competitive interaction between MT and CRIP.

The implications of these results to human health and diabetic nutrition are unclear. Approximately 200 million people worldwide are afflicted with diabetes mellitus (39). Of the approximately 12 million diabetics in the United States, about 1 million have type I or IDDM. Although the STZ-induced diabetic rat is a model of IDDM, the effects of diabetes on $\mathrm{Zn}$ metabolism in human populations may differ markedly from those observed in the animal model. Most importantly, these experiments only examined the effects of short-term diabetes on $\mathrm{Zn}$ absorption and transcellular $\mathrm{Zn}$ transport; thus, the consequences of long-term diabetes and the associated metabolic complications (e.g. hypertension, microvascular disease, retinopathy, and inflammation) on $\mathrm{Zn}$ absorption and metabolism cannot be definitively extrapolated from our results. Also, although hyperphagia resulted in high $\mathrm{Zn}$ intake by the diabetic rats, increased $\mathrm{Zn}$ intake attributable to overconsumption of food probably does not represent a significant health problem to human diabetics for two reasons. First, hyperphagia is minimal in patients with IDDM who receive regular insulin therapy and who are in good glycemic control. Second, although marked hyperphagia may be observed in diabetics with significant hyperglycemia, e.g. noncompliant patients, homeostatic mechanisms that control absorption and excretion seem to regulate $\mathrm{Zn}$ and $\mathrm{Cu}$ status adequately over a fairly wide range of intakes.

Our evidence that diabetic rats consumed excess $\mathrm{Zn}$ as a result of disease-induced hyperphagia emphasizes the need to reevaluate the widely accepted premise that hyperzincuria and low $\mathrm{Zn}$ absorption in diabetics are necessarily indicative of increased risk of $\mathrm{Zn}$ deficiency. Our data clearly reiterate that, although high $\mathrm{Zn}$ excretion and low absorption can be a cause of $\mathrm{Zn}$ deficiency, they also may represent a response to high $\mathrm{Zn}$ intake. It should be remembered, however, that hyperzincuria and low $\mathrm{Zn}$ absorption may be either a cause of $\mathrm{Zn}$ deficiency or an effect of diabetic hyperphagia at different stages of the disease. For example, hyperphagia in uncontrolled diabetes may contribute to elevated $\mathrm{Zn}$ intake and up-regulation of homeostatic mechanisms to limit $\mathrm{Zn}$ retention. In contrast, long-term diabetes may adversely affect components of the $\mathrm{Zn}$ transport and excretion mechanisms, thereby increasing the susceptibility of the subject to $\mathrm{Zn}$ deficiency. Thus, although some studies have recommended $\mathrm{Zn}$ supplementation for diabetic patients because of the perceived potential for $\mathrm{Zn}$ deficiency $(15,17)$, our results indicate that food and $\mathrm{Zn}$ intake and $\mathrm{Zn}$ status should be carefully evaluated on a case-by-case basis before prescription of a $\mathrm{Zn}$ supplement. Incorporating these assessments into the patient's evaluation before supplementation would avoid exacerbating the potential adverse effects of a preexisting high $\mathrm{Zn}$ intake $(18,19)$.
In summary, these experiments showed that the STZinduced diabetic rat is a useful model for the evaluation of $\mathrm{Zn}$ transport mechanisms and further substantiate the proposed antagonistic roles of MT and CRIP in carrier-mediated transcellular intestinal $\mathrm{Zn}$ transport. These data also suggest that decreased $\mathrm{Zn}$ absorption in the diabetic rat is a beneficial homeostatic response to hyperphagia and high $\mathrm{Zn}$ intake rather than a disease-related defect in $\mathrm{Zn}$ transport. The results showed that excess $\mathrm{Zn}$ intake, and the up-regulation of mechanisms to limit $\mathrm{Zn}$ absorption and maintain homeostasis, can result from overconsumption of a diet with a moderate $\mathrm{Zn}$ content. Whether this relationship between food intake and altered $\mathrm{Zn}$ metabolism can be extrapolated to diabetic humans, or represents a significant health concern, is uncertain. But further studies to evaluate the effects of long-term diabetes on $\mathrm{Zn}$ transport and the potential adverse effects of high $\mathrm{Zn}$ intake on $\mathrm{Cu}$ metabolism by diabetics seem warranted.

\section{REFERENCES}

1. Heise CC, King JC, Costa FM, Kitzmiller JL 1988 Hyperzincuria in IDDM women Relationship to measures of glycemic control, renal function, and tissue catabolism Diabetes Care 11:780-786

2. Walter RM Jr, Uriu Hare JY, Olin KL, Oster MH, Anawalt BD, Critchfield JW, Keen CL 1991 Copper, zinc, manganese, and magnesium status and complications of diabetes mellitus. Diabetes Care 14:1050-1056

3. Canfield WK, Hambidge KM, Johnson LK 1984 Zinc nutriture in type I diabetes mellitus: relationship, to growth measures and metabolic control. J Pediatr Gastroenterol Nutr 3:577-584

4. McNair P, Kiilerich S, Christiansen C, Christensen MS, Madsbad S, Transbol I 1981 Hyperzincuria in insulin treated diabetes mellitus: its relation to glucose homeostasis and insulin administration. Clin Chim Acta 112:343-348

5. Brun JF, Fons C, Fussellier M, Bardet L, Orsetti A 1992 Urinary zinc and its relationships with microalbuminuria in type I diabetics. Biol Trace Elem Res 32:317323

6. Lau AL, Failla ML 1984 Urinary excretion of zinc, copper and iron in the streptozotocin-diabetic rat. J Nutr 114:224-233

7. Failla ML, Gardell CY 1985 Influence of spontaneous diabetes on tissue status of zinc, copper, and manganese in the BB Wistar rat. Proc Soc Exp Biol Med 180:317322

8. Levine AS, McClain CJ, Handwerger BS, Brown DM, Morley JE 1983 Tissue zinc status of genetically diabetic and streptozotocin-induced diabetic mice. Am J Clin Nutr 37:382-386

9. Song MK, Mooradian AD 1988 Intestinal zinc transport: influence of streptozotocininduced diabetes, insulin and arachidonic acid. Life Sci 42:687-694

10. Kinlaw WB, Levine AS, Morley JE, Silvis SE, McClain CJ 1983 Abnormal zinc metabolism in type II diabetes mellitus. Am J Med 75:273-277

11. Ghishan FK, Greene HL 1983 Intestinal transport of zinc in the diabetic rat. Life Sci 32:1735-1741

12. Craft NE, Failla ML 1983 Zinc, iron, and copper absorption in the streptozotocindiabetic rat. Am J Physiol 244:E122-E128

13. Kiilerich S, Hvid Jacobsen K, Vaag A, Sorensen SS 1990 65-Zinc absorption in patients with insulin-dependent diabetes mellitus assessed by whole-body counting technique. Clin Chimı Acta 189:13-18

14. Uriu Hare JY, Walter Jr RM, Keen CL 1992 65-Zinc metabolism is altered during diabetic pregnancy in rats. J Nutr 122:1988-1998

15. Niewoehner CB, Allen JI, Boosalis M, Levine AS, Morley JE 1986 Role of zinc supplementation in type II diabetes mellitus. Am J Med 81:63-68

16. Failla ML, Kiser RA. 1981 Altered tissue content and cytosol distribution of trace metals in experimental diabetes. J Nutr 111:1900-1909

17. McCarty MF, Rubin EJ 1984 Rationales for micronutrient supplementation in diabetes. Med Hypotheses 13:139-151

18. Prasad AS, Brewer GJ, Schoomaker EB, Rabbani PI 1978 Hypocupremia induced by zinc therapy in adults. JAMA 240:2166-2168

19. Gyorffy EJ, Chan H 1992 Copper deficiency and microcytic anemia resulting from prolonged ingestion of over-the-counter zinc. Am J Gastroenterol 87:1054-1055

20. Richards MP, Cousins RJ 1975 Mammalian zinc homeostasis: requirement for RNA and metallothionein synthesis. Biochem Biophys Res Commun 64:1215-1223

21. Cousins RJ 1985 Absorption, transport, and hepatic metabolism of copper and zinc: special reference to metallothionein and ceruloplasmin. Physiol Rev 65:238-309

22. Uriu Hare JY, Stern JS, Keen CL 1988 The effect of diabetes on the molecular localization of maternal and fetal zinc and copper metalloprotein in the rat. Biol Trace Elem Res 18:71-79

23. Hempe JM, Carlson JM, Cousins RJ 1991 Intestinal metallothionein gene expression and zinc absorption in rats are zinc-responsive but refractory to dexamethasone and interleukin 1 alpha. J Nutr 121:1389-1396 
24. Hidaigo J, Campmany L, Borras M, Garvey JS, Armario A 1988 Metallothionein response to stress in rats: role in free radical scavenging. Am J Physiol 255:E518E524

25. Wang Z, Atkinson SA, Bertolo RF, Polberger S, Lonnerdal B 1993 Alterations in intestinal uptake and compartmentalization of zinc in response to short-term dexamethasone therapy or excess dietary zinc in piglets. Pediatr Res 33:118-124

26. Cousins RJ, Leinart AS 1988 Tissue-specific regulation of zinc metabolism and metallothionein genes by interleukin 1. FASEB J 2:2884-2890

27. Bonewitz RF, Foulkes EC, O'Flaherty EJ, Hertzberg V 1982 The effect of dexamethasone on the kinetics of jejunal zinc uptake and metallothionein synthesis in the rat. Dev Toxicol Environ Sci 9:203-214

28. Mengheri E, Murgia C, Vignolini F, Nobili F, Gaetani S 1993 Metallothionein gene is expressed in developing rat intestine and is induced by zinc but not by corticosteroids. J Nutr 123:817-822

29. Hempe JM, Cousins RJ 1991 Cysteine-rich intestinal protein binds zinc during transmucosal zinc transport. Proc Natl Acad Sci USA 88:9671-9674

30. Hempe JM, Cousins RJ 1992 Cysteine-rich intestinal protein and intestinal metallothionein: an inverse relationship as a conceptual model for zinc absorption in rats. $J$ Nutr 122:89-95

31. Birkenmeier EH, Gordon JI 1986 Developmental regulation of a gene that encodes a cysteine-rich intestinal protein and maps near the murine immunoglobulin heavy chain locus. Proc Natl Acad Sci USA 83:2516-2520
32. Needleman DS, Leeper LL, Nanthakumar NN, Henning SJ 1993 Hormonal regulation of the mRNA for cysteine-rich intestinal protein in rat jejunum during maturation. $J$ Pediatr Gastroenterol Nutr 16:15-22

33. Levenson CW, Shay NF, Lee-Ambrose LM, Cousins RJ 1993 Regulation of cysteinerich intestinal protein by dexamethasone in the neonatal rat. Proc Natl Acad Sci USA 90:712-715

34. Levenson CW, Shay NF, Hempe JM, Cousins RJ 1994 Expression of cysteine-rich intestinal protein in rat intestine and transfected cells is not zinc dependent. J Nutr 124:13-17

35. American Institute of Nutrition 1977 Report of the American Institute of Nutrition ad hoc committee on standards for nutritional studies. J Nutr 107:1340-1348

36. American Institute of Nutrition 1980 Second report of the American Institute of Nutrition ad hoc committee on standards for nutritional studies. J Nutr 110:1726

37. National Research Council, Committee on Care and Use of Laboratory Animals, Institute of Laboratory Animal Resources Commission on Life Sciences. 1985 Guide for the Care and Use of Laboratory Animals. National Institutes of Health, Bethesda, MD

38. Williams M, Mayhew TM 1992 Responses of enterocyte microvilli in experimental diabetes to insulin and an aldose reductase inhibitor (ponalrestat). Virchows Arch [B] 47:263-270

39. Olson C 1988 Diagnosis and Management of Diabetes Mellitus. Raven Press, New York 